\title{
DETECTION OF CANTHARIDIN-RELATED COMPOUNDS IN Mylabris impressa
} (COLEOPTERA: MELOIDAE)

\section{NIKBAKHTZADEH M. R. (1), EBRAHIMI B. (2)}

(1) Department of Medical Parasitology and Entomology, College of Medical Sciences, Tarbiat Modares University, Tehran, Iran; (2) Department of Entomology, Ohio State University, Columbus, Ohio State, USA.

ABSTRACT: Cantharidin is mainly found in the beetle families Meloidae and Oedemeridae (Insecta: Coleoptera) which are the natural producers of this terpene anhydride. Most studies to date have focused on cantharidin distribution in blister beetles, with few reports on recently found cantharidin-related compounds (CRCs). Using gas chromatography-mass spectrometry (GC-MS), the present work reported cantharidin and two CRCs, palasonin and cantharidinimide from Mylabris impressa stillata (Baudi, 1878) which was collected from Toyserkan county, Hamedan Province, Iran. Ionization provided mass spectra with characteristic fragments of cantharidin at $m / z 96$ and 128, demethylcantharidin at $m / z \quad 82$ and 114 , and cantharidinimide at $m / z 70,96$ and 127 . This is the first time that cantharidin and the two CRCs are found in the genus Mylabris which in turn is new to the field of venomous insects.

KEY WORDS: Cantharidin, CRC, palasonin, cantharidinimide, blistering beetle, Meloidae, Mylabris.

CONFLICTS OF INTEREST: There is no conflict.

\section{CORRESPONDENCE TO:}

MAHMOOD REZA NIKBAKHTZADEH, Department of Medical Parasitology \& Entomology, College of Medical Sciences, Tarbiat Modarres University, Chamran \& Ale-Ahmad Exp. Junction, P.O. Box: 14115-331, Tehran, Iran. Phone: +98 (21) 88011001; ext: 3557 . Fax: +98 (21) 88013030. Email: nikbakht m@excite.com. 


\section{INTRODUCTION}

Cantharidin $\left(\mathrm{C}_{10} \mathrm{H}_{12} \mathrm{O}_{4}\right)$, which is mainly found in blister beetles (Coleoptera: Meloidae), is among the most widely known insect natural products $(5,16)$. It is highly toxic to most animals ( $L D_{50}$ for humans: $10-60 \mathrm{mg} / \mathrm{kg}$; intraperitoneal $L D_{50}$ for mice: $1 \mathrm{mg} / \mathrm{kg}$ ) (5). Its reputation principally derives from descriptions of its physiological activities as an aphrodisiac and a blistering agent for humans and livestock. For more than 2000 years, blister beetles in powdered or tincture form have been used medicinally in Europe, China and elsewhere. The ancient Greeks and Romans consumed cantharides as a diuretic and abortifacient as well as an aphrodisiac. Its mode of action as an aphrodisiac is by inhibition of phosphodiesterase and protein phosphatases (PPs) activity and stimulation of $B$ receptors which irritates the genital mucosa, therefore enhancing sensation (21). In mammalian tissue, at least four types of $\mathrm{PPs}$ have been identified: $\mathrm{PP}_{1}, \mathrm{PP}_{2 \mathrm{~A}}, \mathrm{PP}_{2 \mathrm{~B}}$ and $\mathrm{PP}_{2 \mathrm{C}}(4,12)$. Cantharidin and $C R C$ s inhibit the activity of both $\mathrm{PP}_{1}$ and $\mathrm{PP}_{2 \mathrm{~A}}(11-$ 15). In China and South Korea, cantharidin has been commercially formulated along with laboratory evaluation and clinical trials to be prescribed as anti-tumor and anticancer agent in humans $(11,19,22)$.

Most chemical studies to date have focused on cantharidin distribution in blister beetles, with few reports on recently found CRCs. Working on meloid beetles, the present study reported two further CRCs from Mylabris impressa stillata (Baudi, 1878 ), which is new to the field of venomous insects.

\section{MATERIALS AND METHODS}

\section{Beetle Collection}

Specimens of Mylabris impressa stillata (Baudi, 1878) were manually collected from Toyserkan county, Hamedan province, Iran, by inspection while they were sitting on flowers or stems of different wild shrubs of the family Asteraceae. The specimens were placed in small net ported plastic boxes $(18 \times 13 \times 6 \mathrm{~cm})$, bottom covered with a layer of wet kitchen paper, and transferred to the laboratory where they were immediately frozen at $-30^{\circ} \mathrm{C}$.

\section{Extract Preparation}

Tissue samples were put into test tubes and their dry weight determined after $36 \mathrm{~h}$ of freeze-drying $\left(-50^{\circ} \mathrm{C}, 9 \times 10^{-2} \mathrm{mbar}\right)$ using a LYOVAC GT2-E freeze-dryer (AMSCO/ 
FINN-AQUA Co. Ltd.). Body fragments were hydrolyzed in small fused test tubes using 100-300 $\mathrm{\mu l} 6 \mathrm{~N}$ hydrochloric acid (Technical $\mathrm{HCl}, 31-33 \%$, AUG. Headinger, Stuttgart, Germany) at $120^{\circ} \mathrm{C}$ for $4 \mathrm{~h}$ in order to remove biomatrix and to set the bound cantharidin free. Following a short period of cooling down, an equivalent

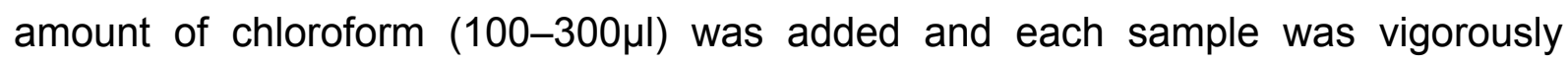
shaken on a Vortex mixer for 60s. Afterwards, samples were centrifuged (Medifuge centrifuge, Heraeus Sepatech $\mathrm{GmbH}$, Osterode, Germany) at 3000rpm for $5 \mathrm{~min}$. Using Pasteur pipette, the organic phase (chloroform-based compounds which stand at the bottom) of each tube was filtered and transferred into a conical 3-dram lip glass vial (10). All glassware used had been already silanized for $24 \mathrm{~h}$ by dimethyldichlorosilane solution I in heptane $5 \%\left(\mathrm{C}_{2} \mathrm{H}_{6} \mathrm{Cl}_{2} \mathrm{Si}\right.$, Fluka).

\section{Quantitative Gas Chromatography-Mass Spectrometry}

To detect CRCs, GC-MS was used and $0.5 \mu$ of each sample splitlessly injected by a $1 \mu l$ microsyringe (SGE, Australia) into the injector. Authentic cantharidin (purity $98 \%$, SIGMA-ALDRICH Chemical Co., UK) served as standard for identification. Relatively high volatility and good thermal stability are those characters of cantharidin which makes GC analysis the method of choice. Capillary GC sensitivities are very good and the typical high resolution achieved with capillary GC permits analyses of substances from biomatrices with minimal sample preparation. Instrumental analyses were performed using a Hewlett-Packard 6890 series gas chromatograph (Agilent Technologies, Wilmington, DE) equipped with a J\&W Scientific (Agilent Technologies, Wilmington, DE) DB-5 capillary column (film thickness: $0.25 \mu \mathrm{m}$, inner diameter: $0.32 \mathrm{~mm}$, length: $30 \mathrm{~m}$ ) connected to a flame ionization detector. The temperature program used for analysis went from 60 to $160^{\circ} \mathrm{C}$ at a rate of $10^{\circ} \mathrm{C} / \mathrm{m}$, holding for $3 \mathrm{~min}$, then to $300^{\circ} \mathrm{C}$ at the rate of $10^{\circ} \mathrm{C} / \mathrm{m}$ and a final hold at $300^{\circ} \mathrm{C}$ for $5 \mathrm{~min}$. Mass spectra were taken at $70 \mathrm{eV}$ with scanning speed of $1 \mathrm{scan} / \mathrm{s}$ from $\mathrm{m} / \mathrm{z} 50$ to 250 while the detector delayed for $5 \mathrm{~min}$. Helium (carrier gas) flow was $3.8 \mathrm{ml} / \mathrm{min}$ and the injector and detector temperatures respectively set at 250 and $300^{\circ} \mathrm{C}$. Ionization provided mass spectra with characteristic fragments of cantharidin at $\mathrm{m} / \mathrm{z}$ 96 and 128 (Figure 1), demethylcantharidin at $\mathrm{m} / \mathrm{z} 82$ and 114 (Figure 2), and cantharidinimide at $\mathrm{m} / \mathrm{z} 70,96$ and 127 (Figure 3). Integration of chromatographic peak areas was performed using Chemstation (revision A.07.01; Hewlett Packard). 


\section{RESULT AND DISCUSSION}

In the animal kingdom, cantharidin is only produced by blister beetles (Coleoptera: Meloidae) and smaller oedemerid beetles (Coleoptera: Oedemeridae), in which it is found in hemolymph and various tissues (2, 3, 5, 7, 9). Cantharidin also acts as a potent attractant to minute fractions within various insect taxa. Living and especially dead meloids and oedemerids and even their cantharidin-containing feces are highly attractive to these so-called canthariphilous insects. They sequester the compound but cannot produce it de novo.

Cantharidin has not been discovered in plants; however, insecticidal seeds of the Himalayan tree, Butea frondosa (Leguminosae), contain demethylcantharidin (palasonin), in which the 3-methyl group of cantharidin is missing $(1,5,20)$. Palasonin is the first CRC that has been so far recorded from the meloids. Dettner et al. (6) were the first who reported palasonin from the South African blister beetle, Hycleus lunatus. Nikbakhtzadeh (18) detected palasonin in Hycleus polymorphus and Mylabris quadripunctata from southern France and Cyaneolytta sp. from the Nairobi's suburbs in East Africa. Unlike the plant source, the beetle-derived palasonin is of low enantiomeric excess with $(R)-(+)$-enantiomer prevailing (8). Dettner et al. (6) also reported the second $\mathrm{CRC}$, palasoninimide, from $H$. lunatus. Another $\mathrm{CRC}$ is cantharimide whose anhydride oxygen atoms are replaced by the basic amino acids L-lysine, L-ornithine and L-arginine moieties and was reported from Mylabris phalerata Pall. (17). Apart from cantharidin and palasonin, low amount of cantharidinimide could be traced in the extract of Mylabris impressa stillata. Although toxicity is decreased in CRCs, all of them remain toxic to most birds, reptiles and, in particular, mammals and are still counted as capable feeding inhibitors. 


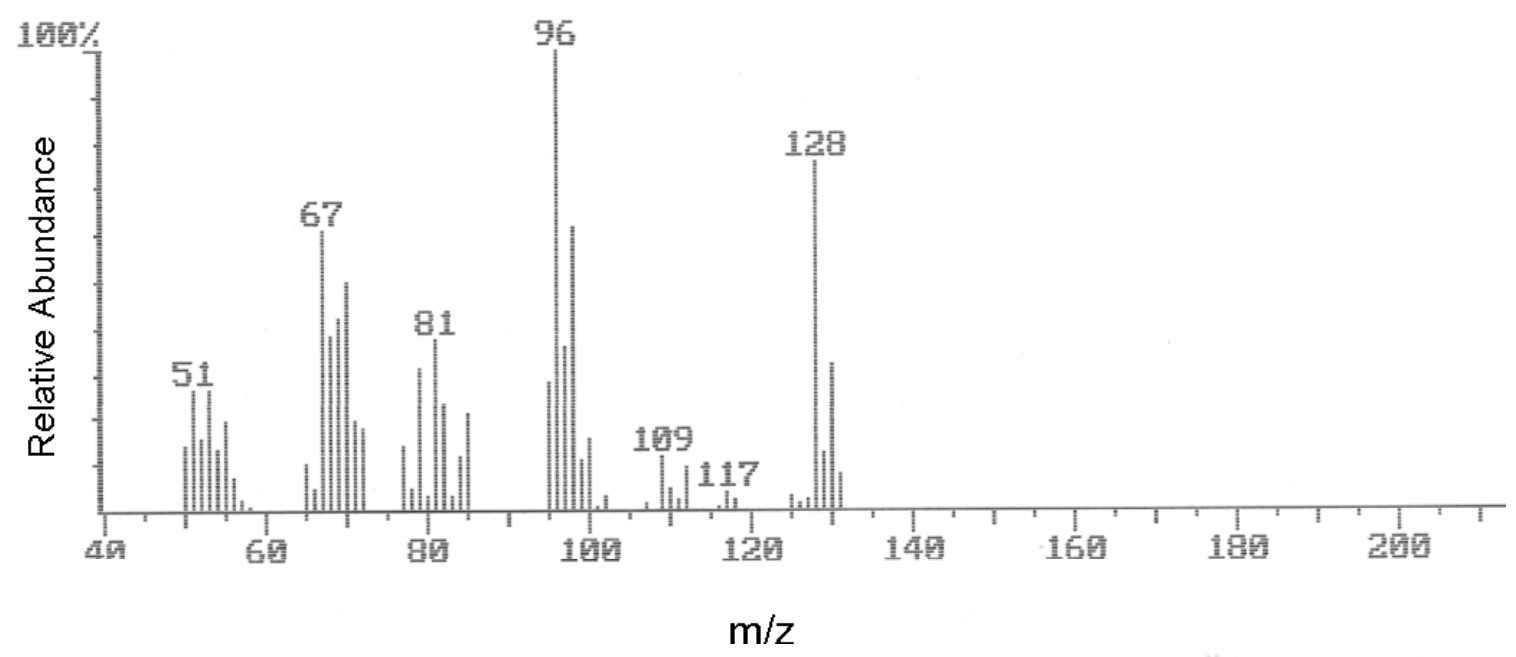

Figure 1. Mass spectra of cantharidin with base peaks at $\mathrm{m} / \mathrm{z} 128$ and 96 according to a Hewlett-Packard gas chromatograph.

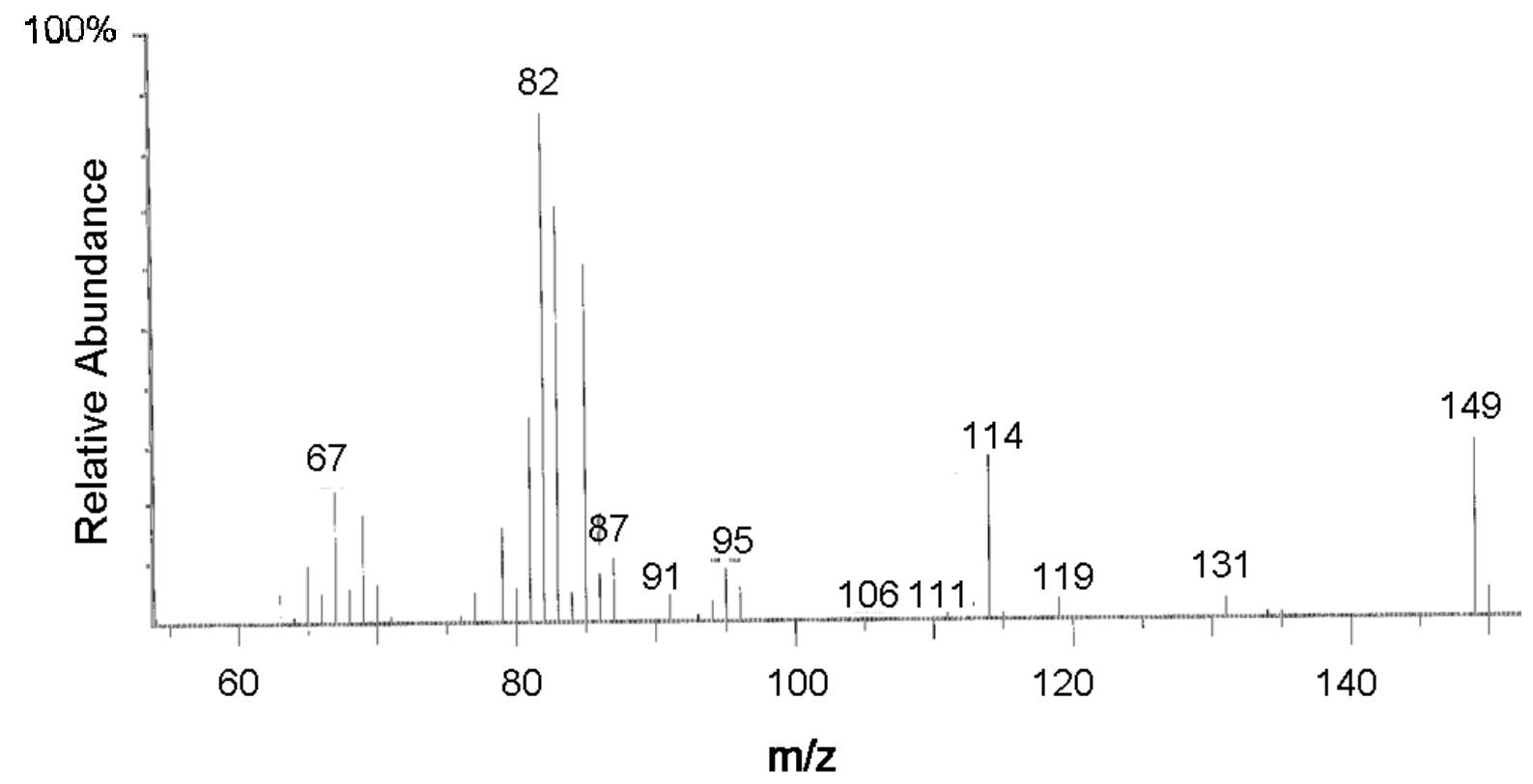

Figure 2. Mass spectra of demethylcantharidin with base peaks at $\mathrm{m} / \mathrm{z} 114$ and 82 according to a Hewlett-Packard gas chromatograph. 


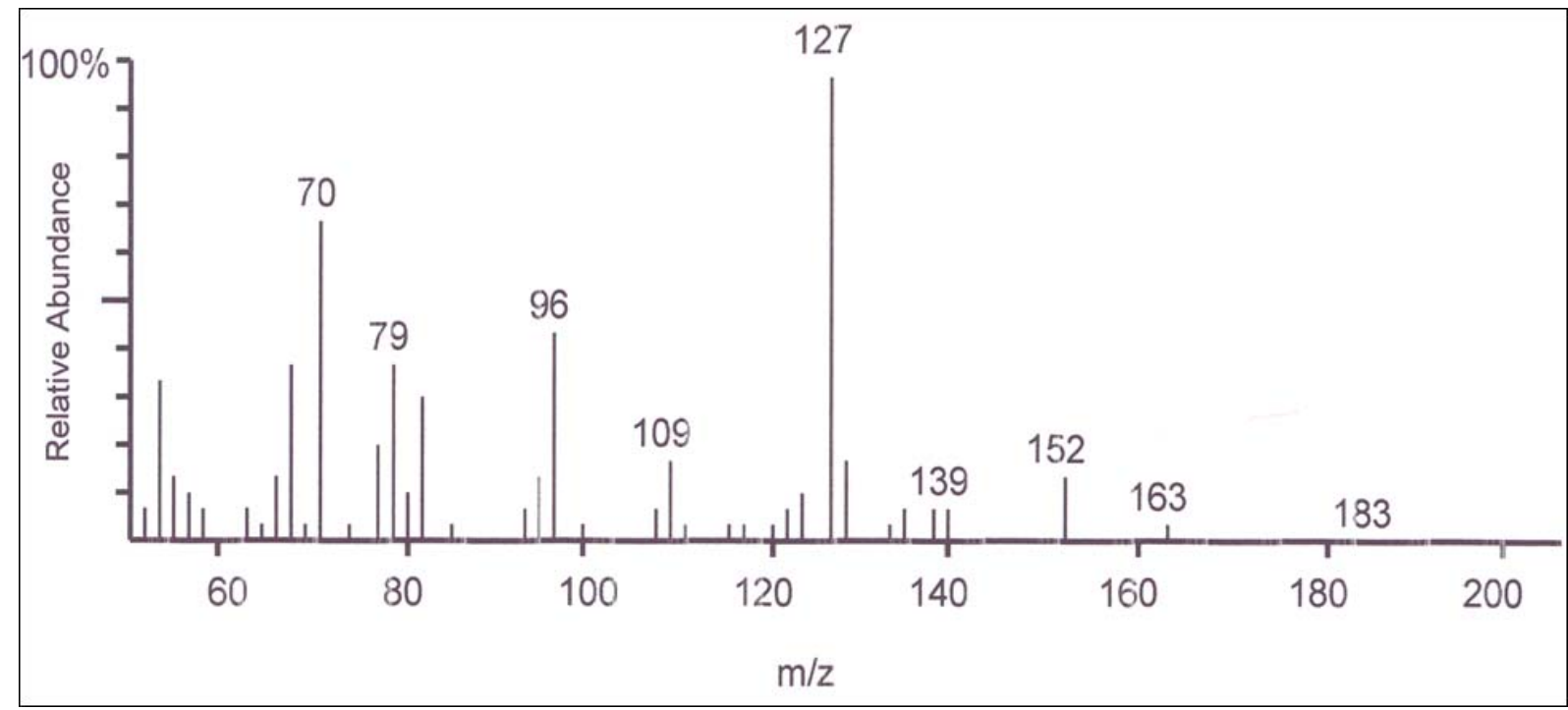

Figure 3. Mass spectra of cantharidinimide with base peaks at $m / z 70,96$ and 127 according to a Hewlett-Packard gas chromatograph.

\section{ACKNOWLEDGEMENTS}

The authors would like to express their gratitude to Professor Dr. Konrad Dettner and Dr. Claudia Hemp, University of Bayreuth, Germany, who transferred the know-how of bioorganic compound detection to us and provided us with lots of skills and documents. This project was financially supported by Tarbiat Modarres University, Tehran, Iran.

\section{REFERENCES}

1 BOCHIS J. The structure of palasonin. Tetrahed. Lett., 1960, 16, 1971-4.

2 CARREL JE., DOOM JP., MCCORMICK JP. Identification of cantharidin in false blister beetles (Coleoptera: Meloidae) from Florida. J. Chem. Ecol., 1986, 12, 741-7. 3 CARREL JE., MCCAIREL MH., SLAGLE AJ., DOOM JP., BRILL J., MCCORMICK JP. Cantharidin production in a blister beetle. Experientia., 1993, 49, 171-4.

4 COHEN P. The structure and regulation of protein phosphatases. Ann. Rev. Biochem., 1989, 58, 453-508.

5 DETTNER K. Inter and intraspecific transfer of toxic insect compound cantharidin. In: DETTNER K., BAUER G., VÖLKL W. Eds. Vertical Food Web Interactions. Berlin: Springer-Verlag, 1997: 115-45. 
6 DETTNER K., SCHRAMM S., SEIDL V., KLEMM K., GÄDE G., FIETZ O., BOLAND W. Occurrence of terpene anhydride palasonin and palasoninimide in blister beetle Hycleus lunatus (Coleoptera: Meloidae). Biochem. Syst. Ecol., 2003, 31, 203-5.

7 DIXON AFG., MARTIN-SMITH M., SMITH SJ. Isolation of cantharidin from Melöe proscarabeus. Can. Pharm. J., 1963, 29, 501-3.

8 FIETZ O., DETTNER K., GÖRLZ H., KLEMM K., BOLAND W. (R)-(+)-Palasonin, a cantharidin-related plant toxin, also occurs in insect hemolymph and tissues. $J$. Chem. Ecol., 2002, 28, 1315-27.

9 FRENZEL M., DETTNER K. Quantification of cantharidin in canthariphilous Ceratopogonidae (Diptera), Anthomyiidae (Diptera) and cantharidin-producing Oedemeridae (Coleoptera). J. Chem. Ecol., 1994, 20, 1795-1812.

10 HOLZ C., STREIL G., DETTNER K., DÜTEMEYER J., BOLAND W. Intersexual transfer of a toxic terpenoid during copulation and its parental allocation to developmental stages: quantification of cantharidin in cantharidin-producing oedemerids (Coleoptera: Oedemeridae) and canthariphilous pyrochroids (Coleoptera: Pyrochroidae). Z. Naturforsch., 1994, 49c, 856-64.

11 JEONG-EUN H., KYUNG-SUN K., CHANHEE C., HYUNG-MIN K., KYOO-SEOK A., SUNG-HOON K. Roles of p38 and JNK mitogen-activated protein kinase pathways during cantharidin-induced apoptosis in U937 cells. Biochem. Pharmacol., 2004, 67, 1811-8.

12 KNAPP J., BOKNIK P., HUKE S., GOMBOSOVA I., LINCK B., LÜSS H., MÜLLER FU., MÜLLER T., NACKE P., SCHMITZ W., VAHLENSIECK U., NEUMANN J. Contractility and inhibition of protein phosphatases by cantharidin. Gen. Pharmacol., 1998, 31, 729-33.

13 LIU XH., BLAZSEK I., COMISSO M., LEGRAS S., MARION S., QUITTET P., ANJO A., WUANG GS., MISSET JL. Effects of norcantharidin, a protein phosphatase type- $2_{\mathrm{A}}$ inhibitor, on the growth of normal and malignant hematopoietic cells. Eur. J. Cancer., 1995, 31A, 953-63.

14 MCCLUSKEY A., KEANE MA., WALKOM CC., BOWYER MC., SIM ATR., YOUNG DJ., SAKOFF JA. The first two cantharidin analogues displaying PP1 selectivity. Bioorg. Med. Chem. Lett., 2002, 12, 391-3.

15 MCCLUSKEY A., WALKOM CC., BOWYER MC., ACKLAND SP., GARDINER E., SAKOFF JA. Cantharimides: a new class of modified cantharidin analogues inhibiting protein phosphatases 1 and 2A. Bioorg. Med. Chem. Lett., 2001, 11, 2941-6. 
16 MCCORMICK JP., CARREL JE. Cantharidin biosynthesis and function in meloid beetles. In: PRESTWITCH GD., BLOMQUIST GJ. Eds. Pheromone Biochemistry. Orlando: Academic Press, 1987. 565p.

17 NAKATANI T., KONISHI T., MIYAHARA K., NODA K. Three novel cantharidinrelated compounds from the Chinese blister beetle, Mylabris phalerata Pall. Chem. Pharm. Bull., 2004, 52, 807-9.

18 NIKBAKHTZADEH MR. Transfer and distribution of cantharidin within selected members of blister beetles (Coleoptera: Meloidae) and its probable importance in sexual behaviour. Bayreuth: Universität Bayreuth, Fakultät für Biologie, Chemie und Geowissenschaften, 2004. 105p. [PhD Thesis].

19 PEMBERTON RW. Insects and other arthropods used as drugs in Korean traditional medicine. J. Ethnopharmacol., 1999, 65, 207-16.

20 RAJ RK., KURUP PA. Isolation and characterization of palasonin, an anthelmintic principle of the seeds of Butea frondosa. Indian J. Chem., 1966, 5, 86-7.

21 SANDRONI P. Aphrodisiacs past and present: a historical review. Clin. Auton. Res., 2001, 11, 303-7.

22 WANG GS. Medical uses of Mylabris in ancient China and recent studies. J. Ethnopharmacol., 1989, 26, 147-62. 